\title{
PERANCANGAN ALAT PENURUN EMISI GAS KARBONMONOKSIDA MENGGUNAKAN MATERIAL TEMBAGA SEBAGAI KATALISATOR PADA MOTOR HONDA BEAT
}

\author{
Erma Yuniati \\ Fakultas Teknologi Industri, Program Studi Teknik Mesin \\ Universitas Jayabaya \\ Email: erma.yuniaty@gmail.com \\ Amin Dwi Prasetyo \\ Fakultas Teknologi Industri, Program Studi Teknik Mesin \\ Universitas Jayabaya \\ Email: amindwiprasetyo50@gmail.com
}

\begin{abstract}
ABSTRAK
Emisi gas buang kendaraan bermotor menyumbang 60-70\% pencemaran udara di Indonesia. Salah satu gas berbahaya yang terkandung didalam gas buang kendaraan bermotor adalah gas karbon monoksida (CO). Emisi gas karbon monoksida dapat dikurangi menggunakan teknologi Catalytic Converter, yaitu penambahan logam katalis yang berfungsi sebagai oksidator gas karbon monoksida (CO) sehingga dapat bereaksi menjadi gas karbon dioksida $\left(\mathrm{CO}_{2}\right)$. Pada umumnya, logam katalis yang digunakan adalah platinum dan palladium. Penelitian sebelumnya menyatakan bahwa tembaga dapat digunakan sebagai logam katalis alternatif. Tembaga berbentuk plat segiempat disusun pada sebuah mur sehingga membentuk sebuah lapisan katalis. Lapisan katalis kemudian dimasukkan kedalam pipa stainless steel yang berfungsi sebagai wadah. Penelitian ini menggunakan variasi 1 lapisan, 2 lapisan, 3 lapisan dan 4 lapisan. Emisi gas CO pada knalpot standar adalah $249.24 \mathrm{ppm}$. Emisi gas CO mengalami penurunan setelah pemasangan katalis tembaga. Emisi gas CO yang dihasilkan disetiap variasi lapisan secara berurutan adalah 235.10 ppm, 204.5 ppm, 176.67 ppm, 159.97 ppm. Semakin banyak lapisan katalis tembaga yang digunakan maka semakin besar luas permukaan (surface area) dari katalisator sehingga emisi gas $\mathrm{CO}$ yang dihasilkan semakin kecil. Katalisator dengan material tembaga dapat digunakan untuk mengurangi emisi gas karbon monoksida pada knalpot kendaraan.
\end{abstract}

Kata kunci: emisi, karbon, katalis, monoksida, MQ-7, tembaga

\section{PENDAHULUAN}

Udara merupakan zat yang paling dibutuhkan oleh setiap mahluk hidup di bumi setelah air. Udara mengandung unsur oksigen yang dibutuhkan oleh mahluk hidup untuk bernafas dan hidup [1]. Kandungan dari gas-gas di udara berbeda-beda tergantung tempat, musim, serta siang atau malam. Unsur utama penyusun udara adalah nitrogen $(\mathrm{N})$ dan oksigen $(\mathrm{O})$. Sisa $1 \%$ gas terdiri dari gas mulia, karbon dioksida, uap air dan pencemar seperti nitrogen oksida [2].

Manusia sebagai mahluk hidup yang memiliki akal berkewajiban untuk menjaga kebersihan dan kelestarian udara dengan tidak melakukan perbuatan yang dapat mencemari lingkungan. Manusia bertanggung jawab penuh untuk segala hal yang menyangkut penyebab dan akibat dari pencemaran yang ada di bumi karena manusia yang menyebabkan hal tersebut terjadi. Pertumbuhan aktivitas ekonomi dan urbanisasi yang cukup tinggi baik diperkotaan dan subperkotaan berpotensi besar dalam meningkatkan penggunaan konsumsi energi, seperti pada kebutuhan bahan bakar guna pembangkit listrik, tungku-tungku industri dan transportasi. Pembakaran bahan bakar ini merupakan sumber-sumber pencemar utama yang dilepaskan ke udara, seperti COx, NOx, SOx, SPM (Suspended Particulate Matter), Ox dan berbagai logam berat [3]. 
Berdasarkan Peraturan Pemerintah RI No.41/1999, pencemaran udara adalah masuknya atau dimasukkannya zat, atau energi, dan/atau komponen lain kedalam udara ambien oleh kegiatan manusia, sehingga mutu udara ambien tidak dapat memenuhi fungsinya. Udara ambien adalah udara bebas yang ada dipermukaan bumi pada lapisan troposfir [4].

Pada tahun 2012, organisasi Perserikatan Bangsa-Bangsa (PBB) khususnya World Health Organization atau WHO yang menangani perihal kesehatan manusia di dunia melaporkan bahwa sekitar 7 juta kematian atau 1/8 kematian di dunia disebabkan oleh pajanan pencemaran udara. Tingkat kematian tertinggi berada di negara-negara berkembang maupun tertinggal seperti Asia Tenggara dan Pasifik Barat dengan jumlah kematian sekitar 6 juta orang [5].

Departemen Kesehatan Republik Indonesia menyatakan pencemaran udara di Indonesia saat ini semakin menghawatirkan. Pencemaran udara tersebut berasal dari berbagai kegiatan manusia antara lain industri, trasportasi, perkantoran, perumahan dan berbagai aktifitas manusia lainnya. Kegiatan-kegiatan tersebut merupakan penyumbang terbesar dari pencemaran udara. Di tingkat pertama yaitu emisi gas buang kendaraan bermotor sebagai sumber polusi udara terbesar mencapai 60-70\%, lebih besar apabila dibandingkan dengan pencemaran udara yang dihasilkan oleh perindustrian yang hanya berkisar antara 10$15 \%$. Oleh karena itu diperlukan sebuah perbaikan sistem kerja kendaraan bermotor guna mengurangi tingkat pencemaran udara yang dihasilkan [6].

Didalam langkah kerja sebuah mesin kendaraan bermotor hingga dapat menghasilkan energi gerak diproduksi limbah berupa gas buang yang mengandung karbon monoksida $(\mathrm{CO}(\mathrm{g}))$, hidrokarbon $(\mathrm{HC}(\mathrm{g}))$, nitrogen oksida (NOx(g)), sulfur oksida (SOx(g)) dan timbal(s). Kandungan setiap kendaraan berbeda-beda bergantung pada jenis bahan bakar serta efisiensi pembakaran yang terjadi pada ruang bakar kendaraan tersebut [7].

Menurut Nevers, kendaraan bermotor merupakan sumber dari pencemaran udara yang menghasilkan emisi CO, dan sekitar 40 - 50 persen juga menghasilkan emisi HC serta NOx. Kendaraan bermotor juga menghasilkan partikulat dan $\mathrm{SO}$, namun kandungan yang dihasilkan tidak sebanyak $\mathrm{CO}, \mathrm{HC}$ dan NOx [8].

Wardhana menjelaskan bahwa karbon monoksida adalah suatu gas yang tidak berwarna, tidak berbau dan tidak berasa. Gas CO dapat berbentuk cairan pada suhu dibawah -192oC. Gas CO sebagian besar berasal dari pembakaran bahan bakar fosil dengan udara sehingga berbentuk gas buangan. Kota besar seperti Jakarta yang memiliki lalu lintas yang padat akan menghasilkan banyak gas CO sehingga kadar CO didalam udara relatif tinggi dibandingkan daerah pedesaan [9].

Monoksida yang terhirup kedalam tubuh manusia dapat mempengaruhi kesehatan, yaitu tekanan fisiologikal terutama pada penderita penyakit jantung, dan keracunan darah. Gas ini dapat menyebabkan penurunan daya tampung darah terhadap oksigen sehingga dapat berpengaruh buruk untuk tubuh manusia [10][11].

Selama ini, uji emisi dilakukan pada waktu-waktu tertentu dan hanya berkonsentrasi pada kendaraan roda empat. Rencananya pihak Dinas Lingkungan hidup DKI Jakarta akan mewajibkan roda dua untuk ikut uji emisi [12]. Untuk menanggulangi pencemaran udara berupa gas karbonmonoksida yang dihasilkan dari gas buang kendaraan bermotor, Pemerintah melalui Peraturan Menteri Negara Lingkungan Hidup RI No.10 tahun 2012 mengatur standarisasi emisi gas buang kendaraan bermotor yang dapat digunakan oleh masyarakat. Aturan ini mengatur ambang batas kandungan gas beracun seperti gas CO (karbon monoksida), gas HC (hidrokarbon) dan gas NOx (oksid nitrogen) yang ada didalam gas buang kendaraan bermotor. Aturan ini telah mengacu pada standar eropa yaitu euro III. Pada kendaraan bermotor tipe baru kategori L dengan metode pengujian I (MODE TEST) yaitu ECE R40 UDC Mode (Cold Start), kendaraan bermotor beroda dua dengan kapasitas silinder kurang dari $150 \mathrm{~cm} 3$ dengan desain kecepatan maksimum lebih dari $50 \mathrm{~km} / \mathrm{jam}$ maka nilai ambang batas parameter gas $\mathrm{CO}$ adalah 2.0 gram/Km [13].

Usaha untuk mengurangi produksi gas $\mathrm{CO}$ dari kendaraan bermotor dibagi menjadi 2 cara, yaitu mengontrol proses karburasi pembakaran pada ruang bakar agar pembakaran lebih sempurna dan menambahkan sebuah alat untuk mengubah gas $\mathrm{CO}$ menjadi gas yang tidak beracun. Namun pengaturan karburasi tidak dapat dilakukan pada kendaraan lama karena performa ruang bakar yang sudah menurun.

Teknologi paling efektif untuk menurunkan emisi gas karbon monoksida adalah menerapkan Catalytic Converter pada sistem gas buang knalpot kendaraan bermotor. Catalytic Converter adalah satu dari teknologi alternatif untuk menurunkan polutan yang dihasilkan kendaraan bermotor, khususnya mesin bahan bakar minyak bumi [14]. Fungsi pemasangan Catalytic Converter pada sistem gas buang dari knalpot 
kendaraan bermotor adalah merubah polutan berbahaya seperti karbon monoksida (CO) dan hidrokarbon (HC) menjadi polutan yang tidak berbahaya seperti gas karbon dioksida (CO2) dan uap air (H2O) [15].

Katalis yang umum digunakan adalah logam mulia seperti Platinum dan Palladium [16]. Tetapi harga dari logam mulia tersebut relatif mahal, ketersediaannya yang langka dan beroperasi pada suhu yang tinggi.

Oleh karena itu penting dilakukan penelitian untuk menurunkan emisi gas karbon monoksida dengan menerapkan teknologi Catalytic Converter pada sistem gas buang di knalpot kendaraan bermotor. Logam yang digunakan adalah logam transisi dengan ketersediaan yang melimpah dan harganya relatif murah sehingga dapat menjadi logam katalis alternatif. Logam tersebut adalah Tembaga (Cu) [17]. Tembaga dipilih sebagai logam katalis karena ketersediaannya yang melimpah, harganya yang relatif murah dan dapat bereaksi pada suhu yang lebih rendah dari logam mulia seperti Platinum. Alat penurun emisi gas CO haruslah mudah dipasang, tidak merubah sistem knalpot sebelumnya, dan dapat menurunkan emisi gas karbon monoksida.

\section{METODOLOGI PENELITIAN}

Dalam penelitian ini, penulis menggunakan metode deskriptif. Teknik pengumpulan data dan informasi yang dibutuhkan sebagai bahan penulisan adalah sebagai berikut :

\section{Studi Kepustakaan ( Study Literature )}

Studi kepustakaan dilakukan dengan cara mempelajari berbagai bacaan dan literatur yang berkaitan dengan permasalahan untuk kemudian di catat dan di rangkum.

2. Penelitian Lapangan ( Field Reserch )

Dilakukan dengan cara mengumpulkan data dan informasi secara langsung dengan mengamati fenomena-fenomena yang terjadi ketika pengujian serta pengamatan untuk mendapatkan data hasil pengujian.

3. Analisa Data

Analisa data dilakukan dengan mencocokkan data yang didapat dari proses penelitian di lapangan dengan teori-teori yang digunakan sebagai landasan penelitian. Berdasarkan perhitungan dan analisa data, maka ditarik sebuah kesimpulan.

\section{HASIL PENELITIAN}

Berdasarkan studi literatur yang diperoleh, maka alat ukur emisi gas buang khususnya gas CO yang akan digunakan adalah Mikrokontroller Arduino Uno R3 dan sensor MQ-7. Selain harganya yang ekonomis, alat ini dipilih karena sudah ada penelitian sebelumnya yang membahas mengenai alat tersebut sebagai alat ukur gas $\mathrm{CO}$.

\subsection{Desain}

Desain dari alat penurun emisi gas CO dirancang sedemikian rupa untuk memaksimalkan proses menurunkan emisi gas buang CO. Desain alat dibuat berdasarkan studi literatur yang dilakukan dengan beberapa modifikasi model dan bentuk. 


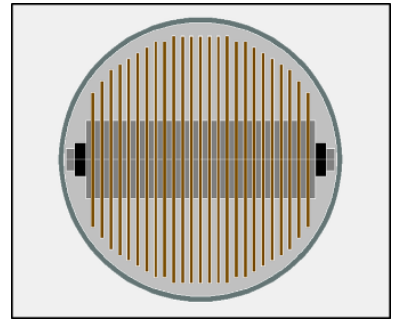

\section{Gambar 3.1 Tampak Depan Alat Penurun Emisi Gas CO}

Bagian yang berwarna jingga merupakan plat tembaga berbentuk persegi panjang. Jumlah plat tembaga per satu buah katalis (1 baris) adalah 23 buah. Ukuran panjang dan lebar plat tembaga yang dibutuhkan sesuai Gambar 1 adalah sebagai berikut :

1. $12 \mathrm{~mm} \times 10 \mathrm{~mm}$, sebanyak 2 buah.

2. $14 \mathrm{~mm} \times 10 \mathrm{~mm}$, sebanyak 2 buah.

3. $16 \mathrm{~mm} \times 10 \mathrm{~mm}$, sebanyak 2 buah.

4. $17 \mathrm{~mm} \times 10 \mathrm{~mm}$, sebanyak 2 buah.

5. $18 \mathrm{~mm} \times 10 \mathrm{~mm}$, sebanyak 2 buah.

6. $19 \mathrm{~mm} \times 10 \mathrm{~mm}$, sebanyak 2 buah.

7. $20 \mathrm{~mm} \times 10 \mathrm{~mm}$, sebanyak 2 buah.

8. $21 \mathrm{~mm} \times 10 \mathrm{~mm}$, sebanyak 4 buah.

9. $22 \mathrm{~mm} \times 10 \mathrm{~mm}$, sebanyak 5 buah.

Jarak antara baris - baris katalis yang dipasang didalam ruang pipa stainless steel dapat dilihat pada Gambar 3.2.

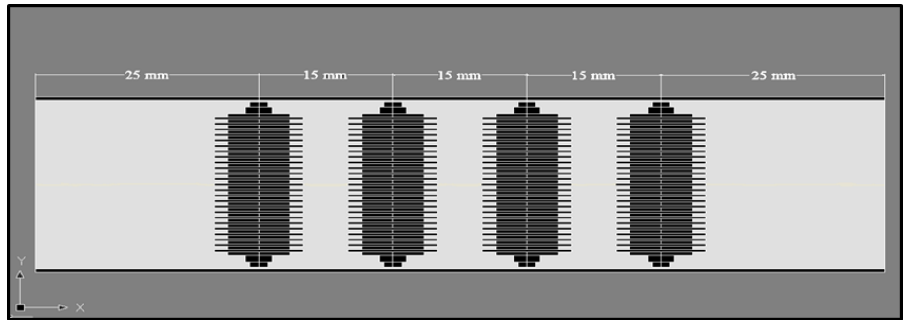

\section{Gambar 3.2 Tampak Atas Alat Penurun Emisi Gas CO dengan 4 Lapisan Katalis}

\subsection{Perancangan Hardware dan Program MQ-7}

Perancangan alat ukur ini didasarkan pada penelitian sebelumnya, meliputi bentuk dan rangkaian kelistrikan yang digunakan oleh Mikrokontroller Arduino Uno R3 dan sensor MQ-7. Software yang digunakan adalah Arduino IDE 1.8.6. Software ini digunakan untuk memprogram Mikrokontroller Arduino Uno R3 sehingga data analog yang dikirimkan sensor MQ-7 dapat diolah sedemikian rupa menghasilkan data jumlah gas CO pada satuan PPM (Part Per Million). Rangkaian kelistrikan komponen hardware dapat dilihat pada Gambar 3.3.

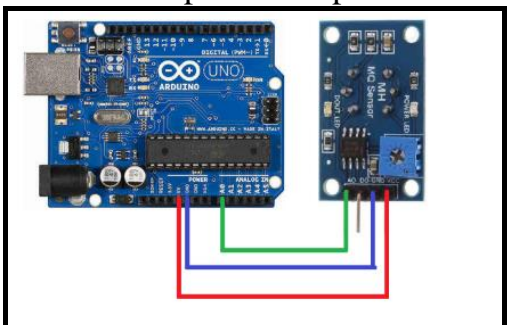

Gambar 3.3 Rangkaian Kelistrikan Hardware 
Rangkaian kelistrikan Hardware yang diperlihatkan pada Gambar 3.6 dihubungkan oleh kabel jumper male-female. Kabel berwarna merah digunakan untuk memberikan suplai daya pada sensor MQ-7. Daya yang digunakan adalah 5Volt. Kabel berwarna biru merupakan kabel grounding (GND) atau disebut kutub negatif dari sensor MQ-7. Kabel berwarna hijau menghubungkan panel A0 yang digunakan untuk mengirimkan sinyal analog dari sensor MQ-7 ke mikrokontroller Arduino Uno R3. Rangkaian kelistrikan dari Gambar 3, dapat dilihat pada Tabel 3.1 .

Tabel 3.1 Rangkaian Kelistrikan

\begin{tabular}{|l|l|l|}
\hline Kabel & Mikrokontroller & Sensor \\
\hline Merah & 5V & VCC \\
\hline Biru & GND & GND \\
\hline Hijau & A0 & A0 \\
\hline
\end{tabular}

Program MQ-7 adalah sebuah program yang digunakan untuk mengoperasikan mikrokontroller Arduino Uno R3 dan sensor MQ-7 dalam proses pengukuran kadar gas CO. Program MQ-7 dimasukkan kedalam mikrokontroller melalui software/aplikasi Arduino IDE 1.8.6. Program ini berisi fungsi persamaan linier PPM $=4.0926 \times(100.227(\mathrm{ADC} / 100)$ yang berasal dari penelitian sebelum nya mengenai kalibrasi data sensor MQ-7. Fungsi tersebut digunakan untuk merubah data ADC (Analog Digital Converter) yang dihasilkan oleh Mikrokontroller Arduino Uno R3 dari proses pengukuran sensor MQ-7 menjadi data kuantitatif gas karbon monoksida pada satuan PPM (Part Per Million).

Program MQ-7 digunakan untuk merubah data ADC menjadi data kadar gas CO dalam satuan PPM (Part Per Million). Data ADC adalah data yang dihasilkan dari pengukuran sensor MQ-7 berupa data pengolahan sinyal analog menjadi sinyal digital oleh mikrokontroller.

Data ADC dikirimkan melalui signal input A0 atau analogRead(A0) kemudian diproses menjadi data sensorValue pada aplikasi Arduino IDE. Kemudian masukkan fungsi PPM $=4.0926$ x (100.227(ADC/100) untuk mengolah data ADC menjadi data PPM. Fungsi tersebut dirubah menjadi fungsi PPM=4.0926*pow $(10,(0.227 *($ sensorValue/100) $))$ ketika dimasukkan kedalam aplikasi Arduino IDE 1.8.6. Sensor volt adalah tegangan yang dihasilkan sensor MQ-7. Data yang dihasilkan sensor MQ-7 memiliki rentang 10-bit atau 1024 data dan daya yang digunakan adalah 5 Volt.

Isi dari Program MQ-7 yang dimasukkan kedalam aplikasi Arduino IDE 1.8.6 dapat dilihat pada Gambar 3.4. 


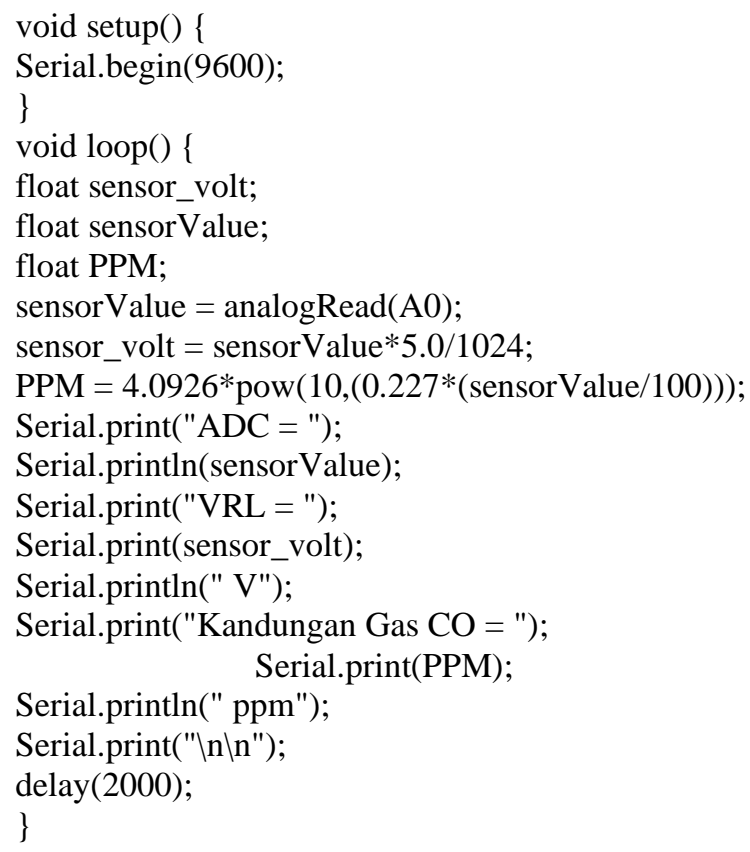

Gambar 3.4 Program MQ-7

\subsection{Integrasi Semua Komponen}

Integrasi semua komponen adalah perakitan komponen hardware dan proses instalasi software pada alat ukur gas CO. Berikut ini merupakan proses integrasi semua komponen hardware dan software.

\subsubsection{Perakitan Komponen Hardware}

Langkah - langkah perakitan komponen hardware alat ukur gas CO adalah sebagai berikut:

a. Mempersiapkan alat dan bahan yang dibutuhkan.

b. Mempersiapkan papan kayu dengan ukuran $20 \mathrm{~cm}$ x $15 \mathrm{~cm}$. Melubangi papan kayu sebagai lubang masuk baut untuk memasang Mikrokontroller Arduino Uno R3 dan Sensor MQ-7.

c. Memasang Mikrokontroller Arduino Uno R3 dan Sensor MQ-7 pada papan kayu dan menempelkan nya menggunakan mur dan baut.

d. Menghubungkan Mikrokontroller Arduino Uno R3 dan Sensor MQ-7 menggunakan Kabel jumper male-female sesuai desain rangkaian kelistrikan pada Gambar 3. 


\section{Gambar 3.5 Alat Ukur Emisi Gas CO Gambar 3.15 Katalis Tembaga}

\subsection{Perakitan Alat Penurun Emisi Gas CO Alat Penurun Emisi Gas CO}

Proses perakitan alat penurun emisi gas CO dilakukan secara bertahap. Proses ini dibagi menjadi 2 bagian, yaitu menyiapkan alat dan bahan yang dibutuhkan serta proses produksi alat penurun emisi gas $\mathrm{CO}$ sesuai desain yang telah dibuat.

Komponen katalis yang sudah siap digunakan dapat dilihat pada Gambar 3.6.

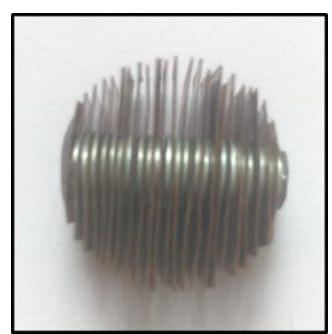

\section{Gambar 3.6 Katalis Tembaga Gambar 3.16 Alat Penurun Emisi Gas CO}

\subsection{Alat Penurun Emisi Gas CO 3.6 Pengambilan Data Emisi Gas CO}

Jika semua komponen sudah terpasang dengan baik sesuai dengan desain gambar, alat siap untuk digunakan dan dipasangkan pada knalpot kendaraan untuk dilakukan pengujian emisi gas CO.

Alat penurun emisi gas CO dapat dilihat pada Gambar 3.7.

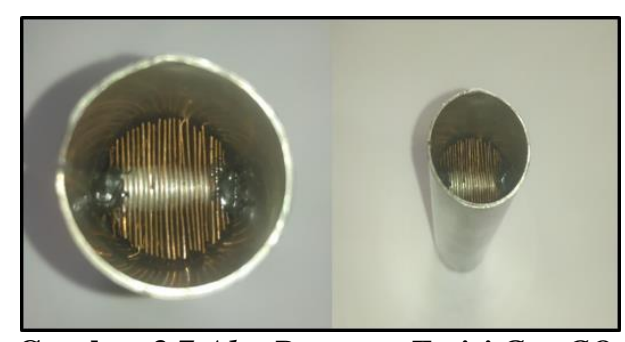

Gambar 3.7 Alat Penurun Emisi Gas CO

\section{PEMBAHASAN}

Pengambilan data dibagi menjadi 2 sesi, yaitu Pengujian 1 dan Pengujian 2. Pengujian 1 adalah proses pengambilan data emisi gas $\mathrm{CO}$ pada knalpot standar tanpa modifikasi. Pengujian 2 adalah proses pengambilan data emisi gas CO pada knalpot yang dipasangi alat penurun emisi gas CO.Pengujian dilakukan di dalam ruangan tertutup. Data diukur dengan kondisi kecepatan putaran mesin 2000 rpm, ko Pengujian kadar emisi gas CO dilakukan pada motor Honda Beat 110cc yang menggunakan bahan bakar Pertalite. Pengukuran emisi gas CO dilakukan dengan sensor MQ-7 berbasis Arduino Uno R3. Emisi gas 
CO diukur pada kecepatan putaran mesin $2000 \mathrm{rpm}$. Untuk mengukur kecepatan putaran mesin digunakan Tachometer yang terhubung pada koil busi kendaraan bermotor.

Pengujian ini menghasilkan data pengamatan berupa nilai ADC (Analog Digital Converter) dan nilai PPM (kadar gas CO dalam satuan ppm). ndisi tanpa beban dan jarak antara sensor MQ-7 dengan lubang keluaran asap knalpot adalah $2 \mathrm{~cm}$ (tetap).

\subsection{Data Pengujian 1}

Pengujian 1 adalah pengukuran emisi gas karbon monoksida yang dilakukan pada knalpot standar. Knalpot standar yang digunakan merupakan knalpot bawaan dari pabrik tanpa modifikasi. Pengukuran dilakukan pada kecepatan putaran mesin $2000 \mathrm{rpm}$.

Data pengukuran yang diperoleh ditampilkan pada menu Serial Monitor pada aplikasi Arduino IDE, untuk lebih jelasnya dapat dilihat pada Gambar 4.1

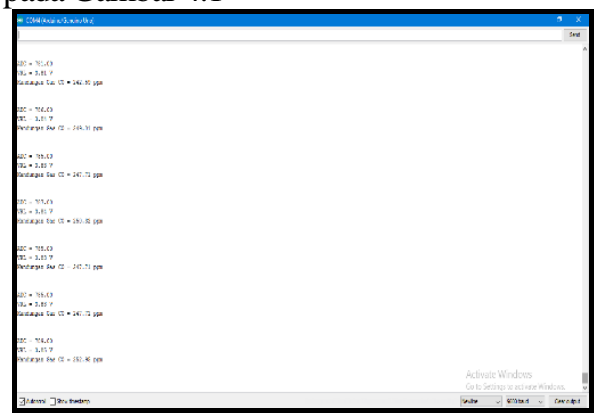

\section{Gambar 4.1 Data Hasil Pengukuran Pada Knalpot Standar}

Berdasarkan analisa data dari beberapa pengujian yang telah dilakukan, emisi gas $\mathrm{CO}$ yang dihasilkan oleh knalpot standar adalah sebagai berikut. Dapat dilihat pada Tabel 4.1.

Tabel 4.1 Data Pengamatan Emisi Gas CO pada Knalpot Standar

\begin{tabular}{|l|l|l|}
\hline \multirow{2}{*}{ No. } & \multicolumn{2}{|l|}{ STANDAR } \\
\cline { 2 - 3 } & ADC & PPM \\
\hline 1 & 786 & 249.01 \\
\hline 2 & 785 & 247.71 \\
\hline 3 & 787 & 250.32 \\
\hline 4 & 785 & 247.71 \\
\hline 5 & 785 & 247.71 \\
\hline 6 & 789 & 252.95 \\
\hline Rerata & & 249.24 \\
\hline
\end{tabular}

Emisi gas CO pada knalpot standar berdasarkan pengujian 1 adalah 249.24 ppm.

\subsection{Data Pengujian 2}

Pengujian 2 adalah pengukuran emisi gas karbon monoksida yang dilakukan pada knalpot modifikasi yang dipasangi alat penurun emisi gas CO di lubang keluaran knalpot. Pengukuran dilakukan pada kecepatan putaran mesin $2000 \mathrm{rpm}$. Pengukuran emisi gas CO dilakukan dengan variasi jumlah katalis yaitu 1 lapisan, 2 lapisan, 3 lapisan dan 4 lapisan.

Disetiap 1 lapisan katalis, terdapat 23 buah plat tembaga. Plat tembaga yang digunakan sebagai katalis berbentuk persegi panjang dengan luas permukaan $=2(\mathrm{PxL})+2(\mathrm{PxT})+2(\mathrm{LxT})$. Luas permukaan plat tembaga per 1 lapisan katalis dapat dilihat pada Tabel 4.2.

Tabel 4.2 Perhitungan Luas Permukaan Plat Tembaga pada 1 Lapisan Katalis 


\begin{tabular}{|c|c|c|c|c|c|c|}
\hline \multirow{2}{*}{ No. } & \multicolumn{3}{|c|}{ Ukuran Plat } & \multirow{2}{*}{$\begin{array}{c}\text { Luas } \\
\text { Permukaan }\end{array}$} & \multirow{2}{*}{$\begin{array}{c}\text { Jumlah } \\
\text { Plat }\end{array}$} & \multirow{2}{*}{$\begin{array}{c}\text { Luas } \\
\text { Permukaan }\end{array}$} \\
\hline & Panjang & Lebar & Tebal & & & \\
\hline 1. & $22 \mathrm{~mm}$ & $10 \mathrm{~mm}$ & $0.3 \mathrm{~mm}$ & $459.2 \mathrm{~mm}^{2}$ & 5 & $2296.0 \mathrm{~mm}^{2}$ \\
\hline 2. & $21 \mathrm{~mm}$ & $10 \mathrm{~mm}$ & $0.3 \mathrm{~mm}$ & $438.6 \mathrm{~mm}^{2}$ & 4 & $1754.4 \mathrm{~mm}^{2}$ \\
\hline 3. & $20 \mathrm{~mm}$ & $10 \mathrm{~mm}$ & $0.3 \mathrm{~mm}$ & $418.0 \mathrm{~mm}^{2}$ & 2 & $836.0 \mathrm{~mm}^{2}$ \\
\hline 4. & $19 \mathrm{~mm}$ & $10 \mathrm{~mm}$ & $0.3 \mathrm{~mm}$ & $397.4 \mathrm{~mm}^{2}$ & 2 & $794.8 \mathrm{~mm}^{2}$ \\
\hline 5. & $18 \mathrm{~mm}$ & $10 \mathrm{~mm}$ & $0.3 \mathrm{~mm}$ & $376.8 \mathrm{~mm}^{2}$ & 2 & $753.6 \mathrm{~mm}^{2}$ \\
\hline 6. & $17 \mathrm{~mm}$ & $10 \mathrm{~mm}$ & $0.3 \mathrm{~mm}$ & $356.2 \mathrm{~mm}^{2}$ & 2 & $712.4 \mathrm{~mm}^{2}$ \\
\hline 7. & $16 \mathrm{~mm}$ & $10 \mathrm{~mm}$ & $0.3 \mathrm{~mm}$ & $335.6 \mathrm{~mm}^{2}$ & 2 & $671.2 \mathrm{~mm}^{2}$ \\
\hline 8. & $14 \mathrm{~mm}$ & $10 \mathrm{~mm}$ & $0.3 \mathrm{~mm}$ & $294.4 \mathrm{~mm}^{2}$ & 2 & $588.8 \mathrm{~mm}^{2}$ \\
\hline 9. & $12 \mathrm{~mm}$ & $10 \mathrm{~mm}$ & $0.3 \mathrm{~mm}$ & $253.2 \mathrm{~mm}^{2}$ & 2 & $506.4 \mathrm{~mm}^{2}$ \\
\hline \multicolumn{6}{|c|}{ Luas Permukaan per 1 Lapisan Katalis } & $8913.6 \mathrm{~mm}^{2}$ \\
\hline
\end{tabular}

Berdasarkan perhitungan pada Tabel 4.4, luas permukaan dari plat tembaga yang dimiliki oleh 1 lapisan katalis adalah $8913.6 \mathrm{~mm} 2$.

Namun karena disetiap 2 buah plat katalis diberikan sebuah ring dengan diameter luar $7 \mathrm{~mm}$ dan penggunaan mur dengan diameter $2 \mathrm{~mm}$. Maka luas permukaan dari setiap plat katalis dikurangi dengan luas dari komponen tersebut. Lubang pada ring tertutupi mur sehingga luas permukaan dari mur dan baut dapat disatukan. Maka luas permukaan dari bagian yang menutupi plat adalah $1 / 4 \square \mathrm{D} 2=0.785 \times(7 \mathrm{~mm}) 2$ yaitu $38.47 \mathrm{~mm} 2$. Dikalikan 2 sisi plat tembaga yang tertutupi yaitu $23 \times 2=46$, sehingga selisih luas permukaan yang didapat adalah $38.47 \mathrm{~mm} 2$ x $46=1769.62 \mathrm{~mm} 2$.

Maka luas permukaan katalis tembaga disetiap 1 lapisan katalis adalah $8913.6 \mathrm{~mm} 2$ dikurangi $1769.62 \mathrm{~mm} 2$ yaitu $7143.98 \mathrm{~mm} 2$. Luas permukaan di setiap variabel pengukuran, dapat dilihat pada Tabel 4.3.

Tabel 4.3 Luas Permukaan Katalis Tembaga di Setiap Variabel Pengukuran

\begin{tabular}{|l|l|l|}
\hline No. & Jumlah Lapisan Katalis & Luas Permukaan \\
\hline 1. & 1 Lapisan & $7143.98 \mathrm{~mm}^{2}$ \\
\hline 2. & 2 Lapisan & $14287.96 \mathrm{~mm}^{2}$ \\
\hline 3. & 3 Lapisan & $21431.94 \mathrm{~mm}^{2}$ \\
\hline 4. & 4 Lapisan & $28575.92 \mathrm{~mm}^{2}$ \\
\hline
\end{tabular}

Alat penurun emisi gas CO merupakan sebuah pipa stainless steel yang didalamnya berisi lapisan lapisan katalis yang terbuat dari susunan plat tembaga. Udara yang keluar dari lubang keluaran asap knalpot akan mengalir kedalam alat penurun emisi gas $\mathrm{CO}$ melalui celah-celah katalis sehingga proses oksidasi gas karbon monoksida dapat terjadi pada permukaan katalis tembaga. Untuk mengetahui luasan dari celah-celah pada alat penurun emisi gas CO maka luas lingkaran dari pipa stainless steel dikurangi luas tampak depan dari lapisan katalis tembaga.

Luas lingkaran dari pipa stainless steel dengan diameter dalam $23 \mathrm{~mm}$ adalah $415.27 \mathrm{~mm} 2$. Sedangkan luas tampak depan dari lapisan katalis tembaga adalah luas tampak depan plat tembaga ditambah luas tampak depan ring. Luas tampak depan dari ring adalah $7 \mathrm{~mm}$ x 0,5 $\mathrm{mm}$ x 24 buah yaitu 84 $\mathrm{mm} 2$. Luas tampak depan dari plat tembaga dapat dilihat pada Tabel 4.4.

Tabel 4.4 Luas Permukaan Tampak Depan dari Plat Tembaga

\begin{tabular}{|l|l|l|l|l|}
\hline No. & Plat Tembaga & Luas & Jumlah & Luas \\
\hline
\end{tabular}




\begin{tabular}{|l|l|l|l|l|l|}
\hline & Panjang & Lebar & & Plat & \\
\hline 1. & $22 \mathrm{~mm}$ & $0.3 \mathrm{~mm}$ & $6.6 \mathrm{~mm}^{2}$ & 5 & $33.0 \mathrm{~mm}^{2}$ \\
\hline 2. & $21 \mathrm{~mm}$ & $0.3 \mathrm{~mm}$ & $6.3 \mathrm{~mm}^{2}$ & 4 & $25.2 \mathrm{~mm}^{2}$ \\
\hline 3. & $20 \mathrm{~mm}$ & $0.3 \mathrm{~mm}$ & $6.0 \mathrm{~mm}^{2}$ & 2 & $12.0 \mathrm{~mm}^{2}$ \\
\hline 4. & $19 \mathrm{~mm}$ & $0.3 \mathrm{~mm}$ & $5.7 \mathrm{~mm}^{2}$ & 2 & $11.4 \mathrm{~mm}^{2}$ \\
\hline 5. & $18 \mathrm{~mm}$ & $0.3 \mathrm{~mm}$ & $5.4 \mathrm{~mm}^{2}$ & 2 & $10.8 \mathrm{~mm}^{2}$ \\
\hline 6. & $17 \mathrm{~mm}$ & $0.3 \mathrm{~mm}$ & $5.1 \mathrm{~mm}^{2}$ & 2 & $10.2 \mathrm{~mm}^{2}$ \\
\hline 7. & $16 \mathrm{~mm}$ & $0.3 \mathrm{~mm}$ & $4.8 \mathrm{~mm}^{2}$ & 2 & $9.6 \mathrm{~mm}^{2}$ \\
\hline 8. & $14 \mathrm{~mm}$ & $0.3 \mathrm{~mm}$ & $4.2 \mathrm{~mm}^{2}$ & 2 & $8.4 \mathrm{~mm}^{2}$ \\
\hline 9. & $12 \mathrm{~mm}$ & $0.3 \mathrm{~mm}$ & $3.6 \mathrm{~mm}^{2}$ & 2 & $7.2 \mathrm{~mm}^{2}$ \\
\hline Luas Tampak Depan Plat Tembaga & $127.8 \mathrm{~mm}^{2}$ \\
\hline \multicolumn{7}{|l|}{}
\end{tabular}

Maka luas dari celah-celah pada alat penurun emisi gas CO adalah $415.27 \mathrm{~mm} 2-(84 \mathrm{~mm} 2+127.8$ $\mathrm{mm} 2)=203.47 \mathrm{~mm} 2$.

Data pengamatan emisi gas CO yang dihasilkan dari pengujian 2 ditampilkan pada menu Serial Monitor pada aplikasi Arduino IDE. Tampilan dari data pengamatan pada variabel 4 lapisan katalis dapat dilihat pada Gambar 4.2.

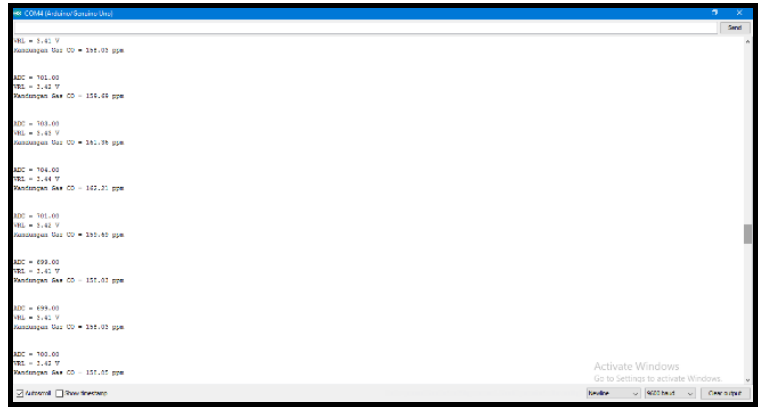

\section{Gambar 4.2 Data Hasil Pengukuran pada Variabel 4 Lapisan Katalis}

Kadar emisi gas CO yang dihasilkan oleh knalpot modifikasi disetiap variasi jumlah katalis dapat dilihat pada Tabel 4.5 .

Tabel 4.5 Data Pengamatan Emisi Gas CO pada Knalpot Modifikasi

\begin{tabular}{|l|l|l|l|l|l|l|l|l|}
\hline \multirow{2}{*}{ No. } & \multicolumn{2}{l}{ 1 Lapisan } & \multicolumn{2}{l|}{ 2 Lapisan } & \multicolumn{2}{l|}{ 3 Lapisan } & \multicolumn{2}{l|}{ Lapisan } \\
\cline { 2 - 9 } & ADC & PPM & ADC & PPM & ADC & PPM & ADC & PPM \\
\hline 1 & 774 & 233.87 & 747 & 203.09 & 720 & 176.36 & 701 & 159.69 \\
\hline 2 & 775 & 235.10 & 751 & 207.38 & 719 & 175.44 & 703 & 161.36 \\
\hline 3 & 775 & 235.10 & 748 & 204.15 & 721 & 177.28 & 704 & 162.21 \\
\hline 4 & 776 & 236.33 & 746 & 202.03 & 723 & 179.15 & 701 & 159.69 \\
\hline 5 & 777 & 237.57 & 743 & 198.89 & 720 & 176.36 & 699 & 158.03 \\
\hline 6 & 773 & 232.65 & 755 & 211.76 & 719 & 175.44 & 700 & 158.85 \\
\hline Rerata & & 235.10 & & 204.55 & & 176.67 & & 159.97 \\
\hline
\end{tabular}


Data pengamatan pada pengujian 2 menunjukkan penurunan emisi gas $\mathrm{CO}$ disetiap variasi jumlah lapisan katalis. Secara berurutan kadar gas CO dari masing - masing variasi jumlah katalis adalah 235.10 ppm, 204.55 ppm, 176.67 ppm dan 159.97 ppm.

\subsection{Perbandingan Hasil Pengujian 1 dan Pengujian 2}

Logam tembaga telah diketahui sebelumnya merupakan salah satu jenis logam yang dapat berfungsi sebagai sebuah katalis oksidator senyawa karbon monoksida (CO). Nilai penurunan gas karbon monoksida akan berbanding lurus dengan jumlah lapisan katalis yang terdapat pada alat penurun emisi gas CO. Hal ini disebabkan semakin banyak jumlah lapisan katalis maka semakin luas sebuah permukaan katalis. Perbandingan hasil pengukuran emisi gas $\mathrm{CO}$ disetiap pengujian yang telah dilakukan dapat dilihat pada Tabel 4.6.

Tabel 4.6 Hasil Pengukuran Emisi Gas CO

\begin{tabular}{|c|c|c|c|c|c|}
\hline \multirow{2}{*}{$\begin{array}{c}\text { Percobaan } \\
\text { ke- }\end{array}$} & \multicolumn{5}{|c|}{ Emisi Gas Karbon Monoksida } \\
\cline { 2 - 6 } & $\begin{array}{c}\text { Standar } \\
(\mathbf{p p m})\end{array}$ & $\begin{array}{c}\text { 1 Lapisan } \\
(\mathbf{p p m})\end{array}$ & $\begin{array}{c}\text { 2 Lapisan } \\
(\mathbf{p p m})\end{array}$ & $\begin{array}{c}\text { 3 Lapisan } \\
(\mathbf{p p m})\end{array}$ & $\begin{array}{c}\text { 4 Lapisan } \\
(\mathbf{p p m})\end{array}$ \\
\hline $\mathbf{1}$ & 249.01 & 233.87 & 203.09 & 176.36 & 159.69 \\
\hline $\mathbf{2}$ & 247.71 & 235.10 & 207.38 & 175.44 & 161.36 \\
\hline $\mathbf{3}$ & 250.32 & 235.10 & 204.15 & 177.28 & 162.21 \\
\hline $\mathbf{4}$ & 247.71 & 236.33 & 202.03 & 179.15 & 159.69 \\
\hline $\mathbf{5}$ & 247.71 & 237.57 & 198.89 & 176.36 & 158.03 \\
\hline $\mathbf{6}$ & 252.95 & 232.65 & 211.76 & 175.44 & 158.85 \\
\hline Rerata & 249.24 & 235.10 & 204.55 & 176.67 & 159.97 \\
\hline
\end{tabular}

Grafik pengukuran disetiap variabel pengukuran yang ditunjukkan oleh Tabel 4.6, dapat dilihat pada Gambar 4.3.

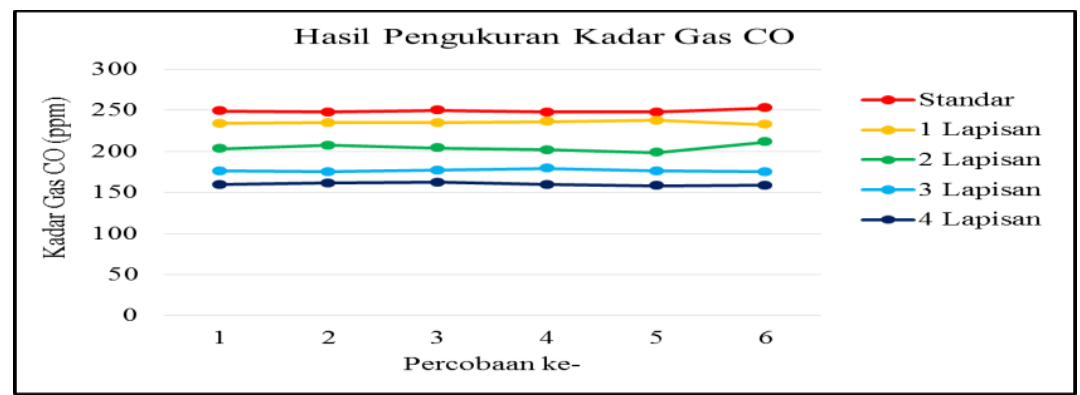

Gambar 4.3 Grafik Hasil Pengukuran Emisi Gas CO

Grafik nilai emisi gas CO yang dihasilkan pada pengujian 1 dan pengujian 2 dapat dilihat pada Gambar 4.4. 


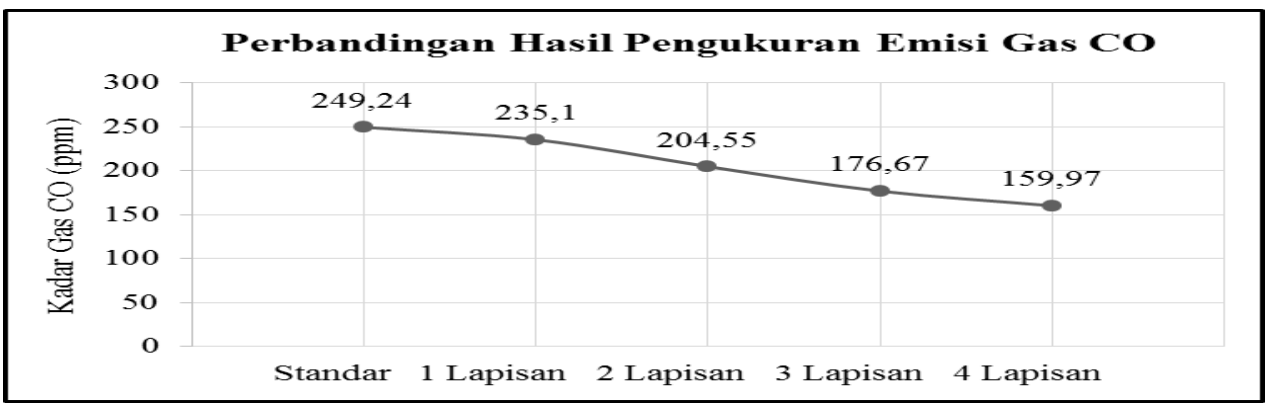

Gambar 4.4 Grafik Perbandingan Nilai Rerata Emisi Gas CO

Pada Gambar 3.3 terlihat grafik penurunan kadar gas CO terbesar terjadi pada alat penurun emisi gas $\mathrm{CO}$ yang memiliki jumlah katalis sebanyak 4 lapisan. Sedangkan penurunan kadar gas CO terendah terjadi pada alat penurun emisi gas $\mathrm{CO}$ yang memiliki katalis sebanyak 1 lapisan.

\section{KESIMPULAN}

Berdasarkan data-data yang diperoleh berdasarkan hasil pengujian serta membandingkan teori - teori yang ada dengan data pengamata, maka dapat disimpulkan bahwa:

1. Katalisator dengan material tembaga mampu menurunkan emisi gas $\mathrm{CO}$ yang dihasilkan knalpot pada motor Honda Beat. Emisi gas CO yang dihasilkan pada knalpot standar adalah 249.24 ppm. Setelah pemasangan alat penurun emisi gas CO menggunakan tembaga sebagai katalisator nya dengan variasi 1 lapisan, 2 lapisan, 3 lapisan dan 4 lapisan, emisi gas CO yang dihasilkan menjadi 235.10 ppm, 204.55 ppm, 176.67 ppm dan 159.97 ppm.

2. Jumlah lapisan dari katalis tembaga yang digunakan pada Alat Penurun Emisi Gas CO mempengaruhi luas permukaan (surface area) dari katalisator. Semakin besar luas permukaan katalisator maka penurunan emisi gas $\mathrm{CO}$ yang dihasilkan akan semakin besar. Pada variasi 1 lapisan katalis dengan luas permukaan $7143.98 \mathrm{~mm} 2$, emisi gas CO yang dihasilkan adalah $235.10 \mathrm{ppm}$ atau turun sebesar $14.14 \mathrm{ppm}$ (5.67\%). Sedangkan pada variasi 4 lapisan katalis dengan luas permukaan $28575.92 \mathrm{~mm} 2$, emisi gas CO yang dihasilkan adalah $159.97 \mathrm{ppm}$ atau turun sebesar $89.27 \mathrm{ppm}(35.81 \%)$.

3. Alat penurun emisi gas $\mathrm{CO}$ yang menggunakan material tembaga sebagai katalisator dapat digunakan untuk menurunkan emisi gas $\mathrm{CO}$ yang dihasilkan kendaraan bermotor dengan cara memasangnya dilubang keluaran asap knalpot.

\section{DAFTAR PUSTAKA}

[1] Agusnar, H. 2007. “Kimia Lingkungan”. USU Press. Medan

[2] 'Kandungan Gas Di Udara”. Diakses tanggal 18 Juni 201815.56 http://peneliti.id/kandungan-gas-diudara/amp/

[3] Budiyono, Afif. 2001. 'Pencemaran Udara : Dampak Pencemaran Udara pada Lingkungan”. Penerbit : LAPAN

[4] Peraturan Pemerintah Republik Indonesia No. 41 Tahun 1999 tentang Pengendalian Pencemaran Udara.

[5] WHO, 2014. “Ambient Outdoor and Health Quality”. Diakses tanggal 9 Mei 2018. http://www.who.int/phe/health to pics/outdoorair/databases/en/ 
[6] Menteri Kesehatan RI. 2010. "Profil Kesehatan Republik Indonesia Tahun 2009”.

[7] Isnaini, Wahyu Laila. 2012. "Pengaruh Paparan Gas CO Terhadap Kelelahan Kerja pada Pedagang Asongan di Terminal Tirtonadi Surakarta”. Surakarta

[8] Nevers, Noel de. 2000. “Air Pollution Control Engineering”. Second edition. McGraw-Hill International Editions. Tokyo.

[9] Wardhana, Wisnu Arya. 2004. "Dampak Pencemaran Lingkungan”. Penerbit: Andy. Yogyakarta.

[10] Soedomo, M. 2001. “Pencemaran Udara”. Penerbit : ITB Press. Bandung.

[11] Yulianti et all. 2013. “Analisis Konsentrasi Gas Karbon Monoksida (CO) pada Ruas Jalan Gajah Mada Pontianak". Universitas Tanjungpura: Pontianak.

[12] Peraturan Menteri Negara Lingkungan Hidup Republik Indonesia No.10 Tahun 2012 tentang Baku Mutu Emisi Gas Buang Kendaraan Bermotor Tipe Baru Kategori L3.

[13] Harian Kompas. Senin, 23 Oktober 2017. “Siap-Siap, Tahun Depan Sepeda Motor Ikut Uji Emisi”. Penulis : Setyo Adi Nugroho.

[14] Heisler, Heinz. 1995. “Advanced Engine Technology”. London : Willesden Centre.

[15] Degobert, P. “Automobiles and Polutan”. Society of Automotive Engineers”. Inhec 1995, pp 24-372.

[16] Nikit, B, Patel., Saurabah B Patel., Milan S Patel., and Diptesh Patel. 2013. "Catalytic Converter Made of Non-noble Mateial for an Automobile". Journal of Scientific Research \& Development. Vol. 1. Issues 9 : ISSN 2321-0613.

[17] Abinesh, J., Arun Kumah J., and Dinesh Kumar S. 2014. "Minimizations Of Engine Emission by Using Non-noble Material Based Catalytic Converter". Journal of Development Research. Vol. 1. issues 11. pp 2463-2468.

[18] Arya Wardhana, Wisnu. 2001. "Dampak Pencemaran Lingkungan" (edisi revisi)”. Penerbit: Andi. Yogyakarta.

[19] Amqam H dan Hasyim Djaffar M. 2006. "Buku Ajar Pencemaran Udara”. Jurusan Kesehatan Lingkungan. FKM-UNHAS. Makassar.

[20] Tim Badan Eksekutif WALHI. 1998. "Reformasi di Bidang Pengelolaan Lingkungan Hidup".

[21] Aminullah S. 2005. "Sinergis UU 23 tahun 1992 tentang Kesehatan, Peraturan Presiden 7 tahun 2005 tentang RPJMN tahun 2004-2009 Bab 28, dengan UU no 32 tahun2004 tentang Pmerintahan Daerah dalam Melahirkan Visi Baru Kesehatan Indonesia”. Disampaikan pada Seminar Nasional 4 tahun Desentralisasi Kesehatan di Indonesia, Makassar 7-9 Juni 2005.

[22] Morlok, Edward K. 1995. "Pengantar Teknik dan Perencanaan Transportasi”. Erlangga : Jakarta.

[23] Peraturan Menteri Negara Lingkungan Hidup Republik Indonesia No. 10 Tahun 2012 tentang "Baku Mutu Emisi Gas Buang Kendaraan Bermotor Tipe Baru Kategori L3".

[24] www.arduino.cc Tanggal akses 20 Agustus 2018. Pukul 21.00 WIB.

[25] Pradika, G. R., Sumardi, Budi, S. 2010. "Pengendalian Putaran Kipas Ventilator pada Smart Smooking Area Menggunakan Mikrokontroler ATMega 8535 dan Sensor Gas MQ-7”. Jurnal Transmisi, 12:155-159.

[26] "MQ-7 Datasheet - Technical Data MQ-7 Sensor”. Hanwei Electronics CO ., LTD.

[27] Campbell, I.M. 1988. "Catalyst of Surface”. Chapman and Hall. New York. pp. 1-3. 
[28] Matthey, Johnson. 2014. “Dennis Dowden and The Development of Catalyst Science”. Technology Review.

[29] Bosch GmbH, Robert. 1999. “Gasoline-Engine Management”. Automotive Technology Volume 2. Bosch Handbook. Stuttgart, Jerman. Penerbit : Wiley.

[30] Husselbee, William L. 1985. “Automotive Cooling Exhaust, Fuel and Lubricating Systems”. A Prentice Hall Company, Reston, Virginia.

[31] Cholilulloh, M. Sudjada. 2014. "Pengaruh Metallic Catalytic Converter Tembaga Berlapis Krom dan Air Induction System (AIS) terhadap Reduksi Emisi Gas Buang Yamaha New Jupiter MX". Teknik Mesin : Universitas Negeri Surabaya.

[32] Nisa, Khairatun., dkk. 2016. "Desain Innovation of Motorcycle Muffler by Applying Catalytic Converter Based on Non-Noble Material to Reduce Exhaust Emission”. Universitas Negeri Semarang : Semarang. ISSN : 2321-9009.

[33] Cahyono, Arif., dkk. "Pengaruh Katalis Oksida Tembaga + Krom Terhadap Emisi Gas CO, CO2 dan HC pada Kendaraan Bermotor”. Surabaya : Institut Teknologi Surabaya.

[34] Aryanto, Arif., Razif, Muhammad. "Studi Penggunaan Tembaga (Cu) Sebagai Catalytic Converter pada Knalpot Sepeda Motor Dua Tak Terhadap Emisi Gas CO”. Teknik Lingkungan FTSP-ITS. Surabaya

[35] Semuel Kete Sarungallo, I Gusti Putu Raka Agung, Lie Jasa. 2017.’Rancang Bangun Alat Ukur Uji Emisi Gas Karbon Monoksida (CO) Berbasis Mikrokontroler". Teknologi Elektro. Universitas Udayana : Bali.

[36] Hammond, C. R. 2004. “The Element”. Handbook of Chemistry and Physics 81st edition. CRC press. ISBN 0-8493-0485-7.)

[37] Brown, Lester. 2006. "Plan B 2.0 : Rescuing a Planet Under Stress and a Civilization in Trouble". New York : W.W. Norton. Halaman 109. ISBN 0-393-32831-7

[38] Jong, A.M., 1994, “Surface Spectroscopy of Model Catalyst”. Phd. Thesis, Technische Universitiet Findoven.

[39] Jenbacher. 1996. “Spark Ignition Engine Design Vol 3”. Jerman: Jenbacher Energy System.

[40] Munson, Bruce R., Donald F. Young, Theodore H.Okiishi. “ Mekanika Fluida Jilid 2”. Erlangga. 2003.

[41] Nakayama, Y. 2000. “Introduction to Fluid Mechanics”. Butterworth Heintmann.

[42] Sanata, Andi. 2012. "Analisis Variasi Temperatur Logam Katalis Tembaga (Cu) Pada Catalytic Converter Untuk Mereduksi Emisi Gas Karbon Monoksida (CO) dan Hidrokarbon (HC) Kendaraan Bermotor". Jurnal ROTOR, Volume 5 Nomor 1.

[43] Irawan, RM.Bagus. "Rancang Bangun Modifikasi Catalytic Converter Dengan Material Substrat Tembaga (Cu) Pada Saluran Gas Buang Kendaraan Bermotor Untuk Mereduksi Emisi Gas Buang Karbon Monoksida". Staff Pengajar Fakultas Teknik Universitas Muhammadiyah Semarang.

[44] Rosyidah, A. 1998. "Pengaruh Komposisi Katalis Campuran CuO, NiO dan Cr2O3 terhadap Optimasi Oksida Karbon Monoksida”. Tesis Magister. Bidang Khusus Kimia Fisik Program Studi Kimia. Surabaya : Institut Teknologi Surabaya. 